Abstracta Iranica Abstracta Iranica

Revue bibliographique pour le domaine irano-aryen

Volume 22 | 2001

Comptes rendus des publications de 1999

\title{
Az Orshalim tâ Orshalim (From Jerusalem to Jerusalem). Costa Mesa, Mazda, 1999, 275 p.
}

Florence Hellot

\section{(2) OpenEdition}

1 Journals

Édition électronique

URL : http://journals.openedition.org/abstractairanica/37397

DOI : 10.4000/abstractairanica.37397

ISSN : 1961-960X

\section{Éditeur :}

CNRS (UMR 7528 Mondes iraniens et indiens), Éditions de l'IFRI

\section{Édition imprimée}

Date de publication : 15 mai 2001

ISSN : 0240-8910

\section{Référence électronique}

Florence Hellot, «Az Orshalim tâ Orshalim (From Jerusalem to Jerusalem). Costa Mesa, Mazda, 1999, 275 p. », Abstracta Iranica [En ligne], Volume 22 | 2001, document 310, mis en ligne le 18 février 2010, consulté le 13 octobre 2020. URL : http://journals.openedition.org/abstractairanica/37397 ; DOI : https://doi.org/10.4000/abstractairanica.37397

Ce document a été généré automatiquement le 13 octobre 2020.

Tous droits réservés 


\title{
Az Orshalim tâ Orshalim (From Jerusalem to Jerusalem). Costa Mesa, Mazda, 1999, 275 p.
}

\author{
Florence Hellot
}

Cet ouvrage, écrit en persan, est le résultat d'une longue compilation de sources occidentales. Il embrasse l'ensemble de l'histoire du peuple juif et cherche à y repérer le poids des mythes, la genèse des principes religieux et celle des rites. Ce sont d'abord les influences de la Perse et de la Grèce qui sont fouillées, puis le rôle joué par l'exil, le retour, et enfin par l'émergence du christianisme. On assiste à la lente maturation du Talmud. Les chapitres suivants traitent de l'évolution interne des Israélites, répartis en de multiples sectes, puis de leur diaspora, de leur situation à la période médiévale, de l'influence des Lumières et du mouvement Haskala. Une longue partie aborde la montée de l'antisémitisme et l'émergence des idées et du mouvement sionistes. La clarté de l'ensemble fait recommander cet ouvrage à ceux qui sont à la recherche d'une bonne synthèse sur la question.

INDEX

Thèmes : 6.3. Autres religions 
AUTEURS

FLORENCE HELLOT

Paris 